\title{
Effect of Endogenous Opioid Peptides on Acetylcholine Release from the Cat Superior Cervical Ganglion: Selective Effect of a Heptapeptide
}

\author{
D. M. Araujo and B. Collier \\ Department of Pharmacology and Therapeutics, McGill University, Montreal, Quebec H3G 1Y6, Canada
}

\begin{abstract}
The present experiments show the presence of both metenkephalin-like and met-enkephalin-Arg ${ }^{6}-$ Phe $^{7}$-like immunoreactivity in the superior cervical ganglion of the cat; this was determined by radioimmunoassay after high-pressure liquid chromatography separation of tissue extracts. There was measurable efflux of both peptides, as determined by radioimmunoassay of ganglionic perfusates; this measure was increased by thiorphan, an enkephalinase inhibitor. The effect of the 2 peptides on ACh release was determined: The stable analog of methionine-enkephalin, D-Ala ${ }^{2}$-methionine-enkephalinamide, did not affect $A C h$ release from the ganglion; in contrast, methionine-enkephalin-Arg ${ }^{6}-\mathrm{Phe}^{7}$ significantly depressed evoked ACh release. The effect of met-enkephalin-Arg ${ }^{6}-\mathrm{Phe}^{7}$ to decrease $\mathrm{ACh}$ release was antagonized, although only partially, by the opioid antagonist naloxone. Thus, it appears that methionine-enkephalin-Arg'$\mathrm{Phe}^{7}$ alters ACh release from the superior cervical ganglion by acting, at least in part, on a presynaptic opioid receptor. The results suggest that in the cat superior cervical ganglion, the heptapeptide enkephalin might have a significant role in the regulation of synaptic transmission, which is unrelated to its potential function as a precursor for methionine-enkephalin.
\end{abstract}

There is now considerable evidence supporting the idea that neuropeptides coexist with conventional transmitter substances in the nervous system (see, for example, Schultzberg et al., 1978a, b, 1979; Schultzberg, 1984). The functional significance of this colocalization is not always clear, but it is usually considered that the peptide might interact presynaptically or postsynaptically to modify the release or the action of the classical transmitter.

The presence of opioid peptides and precursors has been demonstrated in sympathetic ganglia. Thus, met-enkephalin-like (ME-like) immunoreactivity is evident by histochemical (Schultzberg et al., 1979; Dalsgaard et al., 1982) or radioimmunoassay (DiGiulio et al., 1978, 1979) techniques; and metenkephalin-Arg6-Phe ${ }^{7}$ (MEAP), the carboxyl terminal heptapeptide of preproenkephalin A (Comb et al., 1982; Gubler et

Received May 30, 1986; revised Sept. 26, 1986; accepted Nov. 24, 1986.

This work was funded by the Medical Research Council of Canada. D.M.A. was supported by a studentship from the Faculty of Medicine, McGill University, and from F.C.A.C., Quebec.

Correspondence should be addressed to B. Collier, Department of Pharmacology and Therapeutics, McGill University, 3655 Drummond Street, Rm. 1317, Montreal, Quebec H3G 1Y6, Canada.

Copyright @ 1987 Society for Neuroscience $0270-6474 / 87 / 061698-07 \$ 02.00 / 0$ al., 1982; Noda et al., 1982), is demonstrable by immunohistochemistry (Tang et al., 1982, 1983; Helen et al., 1984).

In certain autonomic ganglia, such as the inferior mesenteric and superior-celiac ganglia of the guinea pig (Konishi et al., $1979,1981)$ and the superior cervical ganglion of rat and rabbit (Dun and Karczmar, 1981), met-enkephalin appears to act presynaptically to reduce ACh release (for review, see Dun, 1983). The effect of MEAP upon transmission at autonomic ganglia has not been studied, although at some neuroeffector sites, such as cholinergic synapses in the guinea pig ileum and adrenergic synapses in the mouse vas deferens, MEAP acts like ME to reduce transmitter release (Audigier et al., 1980; Rossier et al., 1980; Hársing et al., 1984).

The present experiments were undertaken to measure the effect of ME and MEAP on ACh release from the cat superior ccrvical ganglion. The results show that these 2 peptides arc present in measurable quantities in this tissue and that they differ in their ability to affect $\mathrm{ACh}$ release from preganglionic nerve terminals.

\section{Materials and Methods}

Materials. $\left[\gamma-{ }^{32} \mathrm{P}\right]$ ATP $(2-10 \mathrm{Ci} / \mathrm{mmol})$ and Aquasol were purchased from New England Nuclear (Boston, MA). Physostigmine sulfate, choline chloride, choline kinase (EC 2.7.1.32, ATP: choline phosphotransferase), AChE (EC 3.1.1.7, acetylcholine hydrolase, Type V-S), $\alpha$-chloralose, $p$-chloromercurisulfonic acid (PCMS), bacitracin, and naloxone hydrochloride were obtained from Sigma Chemical Co. (St. Louis, MO). The following peptides were purchased from Peninsula Laboratories (San Carlos, CA): methionine-enkephalin (ME), [D-Ala ${ }^{2}$-methionine enkephalinamide (DAEA), methionine enkephalin-Arg ${ }^{6}-\mathrm{Phe}^{7}$ (MEAP), methionine-enkephalin-Arg ${ }^{6}-\mathrm{Gly}^{7}-\mathrm{Leu}^{8}$ (MEAGL) and leu-enkephalin (LE). DAEA and MEAP were also obtained from Sigma Chemical Co. (St. Louis, MO). Tetraphenylboron, sodium salt, was obtained from Aldrich Chemical Co. (Milwaukee, WI); 3-heptanone and trifluoroacetic acid (TFA) were from Eastman Kodak Co. (Rochester, NY). Acetonitrile (HPLC-grade) was bought from Fisher Scientific Co. (Fair Lawn, NJ). Amberlite CG-400 ( $\mathrm{Cl}^{-}$form) was purchased from BDH Chemicals Ltd. (Poole, U.K.) and from Sigma Chemical Co. (St. Louis, MO). ACh chloride was supplied by Hoffmann-La Roche Inc. (Basel, Switzerland). The radioimmunoassay kits for the detection of ME-likc immunorcactivity (sensitivity of $32 \mathrm{pg} / \mathrm{ml}$ ) were purchased from Immunonuclear Corp. (Stillwater, MN). Thiorphan was a generous gift from Dr. Paul Wood (Neuroscience Res., Pharmaceuticals Division, Ciba-Geigy, NJ). Equipment used for liquid chromatography was obtained from WatersMillipore Corp. (Milford, MA).

Ganglion perfusion. Cats $(2.0-4.0 \mathrm{~kg})$ of either sex were anesthetized in nitrous oxide $(2 / 3)$ and oxygen $(1 / 3)$ containing $2 \%$ halothane; anesthesia was maintained by i.v. administration of chloralose $(80 \mathrm{mg} / \mathrm{kg})$. Superior cervical ganglia were isolated and prepared for perfusion according to Kibjakow's (1933) procedure, as described in detail by Collier and Kwok (1982).

Ganglia were perfused $(0.3-0.4 \mathrm{ml} / \mathrm{min})$ with $\mathrm{Krebs}$ solution of the following composition (in $\mathrm{mM}$ ): $\mathrm{NaCl}, 120 ; \mathrm{KCl}, 4.6 ; \mathrm{CaCl}_{2}, 2.4 ; \mathrm{KH}_{2} \mathrm{PO}_{4}$, 
Table 1. Enkephalin-like immunoreactivity of ganglia extracted in $0.1 \mathrm{M}$ acetic acid

\begin{tabular}{lc} 
Peptidase inhibitor & $\begin{array}{l}\text { Immunoreactivity } \\
\text { (pg/ganglion) }\end{array}$ \\
\hline None & $304 \pm 108$ \\
Bacitracin & $353 \pm 88$ \\
PCMS & $1264 \pm 153^{a}$
\end{tabular}

Enkephalin-like immunoreactivity was determined by radioimmunoassay using antibodies to met-enkephalin (see text). The results are expressed as the means \pm SEM of 4-5 ganglia in each set. Enkephalin-like immunoreactivity of ganglia extracted in acid-containing PCMS $\left(10^{-4} \mathrm{M}\right)$ is significantly different from that of ganglia extracted in acid alone and in acid containing bacitracin $\left(2 \times 10^{-5} \mathrm{M}\right)$. ${ }^{a} p<0.01$ (Student's unpaired $t$ test).

$1.2 ; \mathrm{MgSO}_{4} \cdot 7 \mathrm{H}_{2} \mathrm{O}, 1.2$; glucose, 9.8 ; and $\mathrm{NaHCO}_{3}, 25$; this was equilibrated with $5 \% \mathrm{CO}_{2}$ in $\mathrm{O}_{2}$ to maintain a pH of 7.4 at $37^{\circ} \mathrm{C}$. In all cases, the perfusion medium contained choline chloride $\left(10^{-5} \mathrm{M}\right)$ to support ACh synthesis and physostigmine sulfate $\left(1.5 \times 10^{-5} \mathrm{M}\right)$ to allow collection of released $\mathrm{ACh}$; as specified in the text, one or more of the following was added: MEAP, DAEA, MEAGL, thiorphan, and naloxone hydrochloride.

The preganglionic nerve was cut low in the neck and was stimulated with square-wave pulses $(8 \mathrm{~V}, 0.3 \mathrm{mscc})$ delivercd through platinum electrodes. Each stimulation period was $2 \mathrm{~min}$ long, and the frequency of stimulation was $20 \mathrm{~Hz}$.

In experiments that measured $\mathrm{ACh}$ release, ganglia were perfused with Krebs solution containing choline and physostigmine for at least $10 \mathrm{~min}$ before collecting samples for assay. Then, ganglionic effluents were collected as 2 min samples: a 2 min collection with the ganglion at rest was followed by a 2 min collection during which the ganglion was stimulated via the preganglionic sympathetic nerve. Each period of stimulation was separated from the next by a $6 \mathrm{~min}$ rest period. When switching from one perfusion medium to another, there was a $10 \mathrm{~min}$ washout period before collection of the next test samples. Evoked ACh release represents the $\mathrm{ACh}$ released during the $2 \mathrm{~min}$ period of stimulation minus the $\mathrm{ACh}$ released during the preceding 2 min rest period. In each experiment, under cach condition, 2 such tests were made and the value for evoked release was calculated as the average.

Assay for $A C h$. The ACh content of ganglionic effluents was determined by the radioenzymic assay of Goldberg and McCaman (1973), as described by Kwok and Collier (1982). ACh was extracted from ganglionic effluents by tetraphenylboron/heptanone $(10 \mathrm{mg} / \mathrm{ml})$ and recovered from the organic phase by shaking with a half volume of $\mathrm{AgNO}_{3}$ $(0.12 \mathrm{M})$ as described by Fonnum (1969). Excess silver was precipitated by addition of $10 \mu \mathrm{l}$ of $\mathrm{MgCl}_{2}(1 \mathrm{M})$ per $100 \mu \mathrm{l}$ sample. Samples were then lyophilized and redissolved in $32 \mu \mathrm{l}$ of a reaction medium containing ATP (0.8 mM), dithiothreitol (5 mM), $\mathrm{MgCl}_{2}$ (12.5 mM), glycylglycine ( $25 \mathrm{~mm}, \mathrm{pH} 8.3)$, and choline kinase $(0.005 \mathrm{U})$. These samples were incubated at $30^{\circ} \mathrm{C}$ for $30 \mathrm{~min}$ to phosphorylate any endogenous choline in the samples. A solution $(10 \mu \mathrm{l})$ containing AChE $(2 \mathrm{U})$ and ${ }^{32} \mathrm{P}$-ATP (approximately $0.45 \mu \mathrm{Ci}$ ) was added to cach samplc, which was then reincubated for $25 \mathrm{~min}$ at $30^{\circ} \mathrm{C}$. During this second incubation, sample ACh was hydrolyzed and the choline thus formed was phosphorylated $10{ }^{32} \mathrm{P}$-phosphorycholine. After the reaction was terminated by the addition of $100 \mu \mathrm{l}$ ice-cold $\mathrm{NaOH}(50 \mathrm{~mm})$, radioactive phosphorylcholine was separated from unchanged ${ }^{32} \mathrm{P}$-ATP by ion-exchange chromatography on Amberlite CG-400 (converted to formate form) columns, which had been previously equilibrated with $\mathrm{NaOH}(50 \mathrm{~mm})$. Phosphorylcholine was eluted with $3 \mathrm{ml}$ of $\mathrm{NaOH}(50 \mathrm{~mm})$. For each experiment, standard amounts of ACh dissolved in Krebs medium of the same composition as the samples were extracted and assayed along with the test samples.

Assay for enkephalin-like immunoreactivity. Ganglia were extracted with $0.1 \mathrm{M}$ acetic acid, usually containing $10^{-4} \mathrm{M}$ PCMS, to prevent peptide breakdown in vitro; these extracts were neutralized with $1 \mathrm{M}$ sodium hydroxide. Aliquots of ganglionic extracts were lyophilized and peptide content was determined by a radioimmunoassay, using antibodies to ME. The ME antibody used in the assay exhibited $>70 \%$ and $>50 \%$ cross-reactivity with MEAP and MEAGL, respectively, but crossreacted less than $20 \%$ with LE. On HPLC, both leu-enkephalin and MEAGL elute in different fractions from ME and MEAP and can therefore be separated from ME and MEAP. The antibody has also been

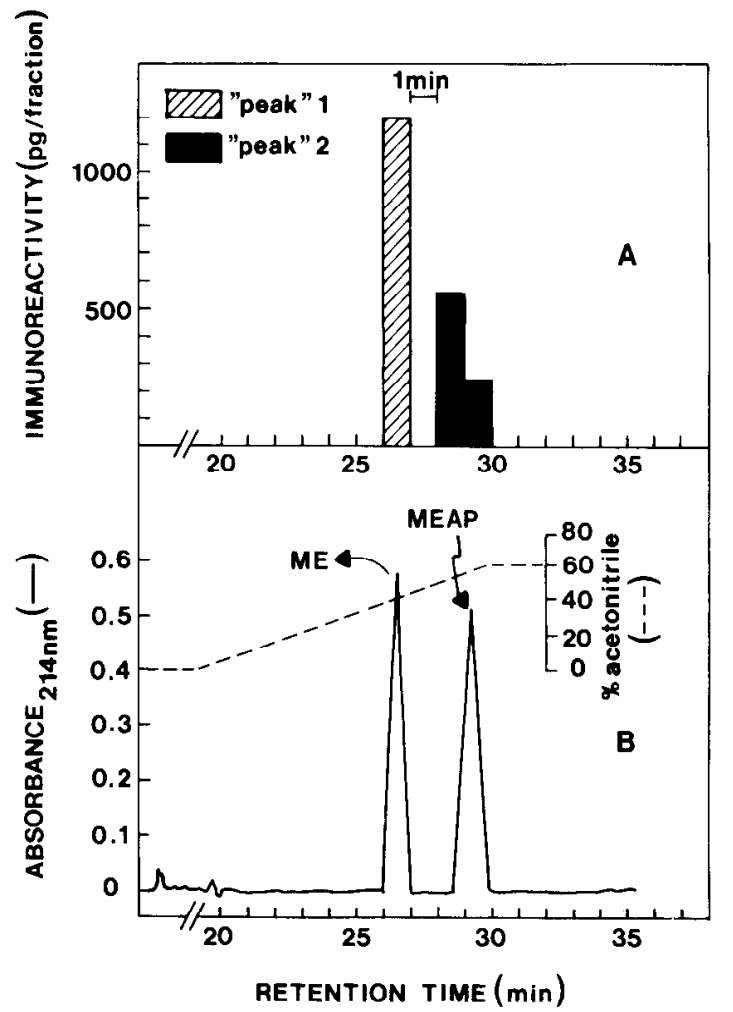

Figure 1. Enkephalin content of ganglia extracted in acid containing PCMS $\left(10^{-4} \mathrm{M}\right)$, subjected to reverse-phase HPLC prior to radioimmunoassay. $A$, Immunoreactivity measured in 1 min fractions. $B, \mathrm{Ab}$ sorbance and retention times of a mixture of standard amounts of ME and MEAP (0.05 $\mathrm{mg}$ each).

tested for cross-reactivity with the following: substance $\mathrm{P}, \beta$-endorphin, $\alpha$-neoendorphin, and dynorphin(1-13); in all cases, the cross-reactivity was $<1 \%$. For determination of enkephalin content of ganglionic perfusates, aliquots of effluents were lyophilized and assayed with the radioimmunoassay described above.

For HPLC separation of peptides, samples were first resuspended in $0.1 \%$ TFA in $25 \%$ acetonitrile and subjected to reverse-phase HPLC on a $\mathrm{C}_{18} \mu$-Bondapak column $(3.9 \mathrm{~mm} \times 30 \mathrm{~cm})$, which was connected to a Guard-PAK precolumn fitted with a $\mathrm{C}_{18}$ insert. Samples were injected into a U6K manual injector. The solvent delivery system consisted of dual model 510 pumps; the pumping rate $(1.0 \mathrm{ml} / \mathrm{min})$ was regulated by a Waters automated gradient controller. The mobile phase through the column consisted of $0.1 \%$ TFA ( $0-10 \mathrm{~min})$; peptides were then eluted, as described by Hersh (1984), with 0.1\% TFA in an acetonitrile gradient $(0-60 \%$ in $20 \mathrm{~min})$. Absorbance, at $214 \mathrm{~nm}$, was detected by a Lambda-Max model 481 LC spectrophotometer and recorded by a 740 Data Module. Fractions were collected using a 2112 Redirac Collector (LKB, Bromma, Sweden), with a lag time of approximately 0.2 min compared to the chromatogram, at 1 or 2 min intervals, lyophilized, and assayed for peptide content as described above. Standard amounts $(0.05 \mathrm{mg})$ of peptides eluted on HPLC with the following average retention times: 26.7, 28.9, 28.0, and 27.3 min for ME, MEAP, MEAGL, and $L E$, respectively.

The peptides (DAEA, MEAP, and MEAGL) used for testing the effect of ACh released from the perfused cat superior cervical ganglion were $97 \%$ pure as determined by HPLC analysis.

Determination of radioactivity. ${ }^{32} \mathrm{P}$ was determined with approximately $100 \%$ efficiency by liquid scintillation spectrometry (LKB) using Aquasol as the solvent system. ${ }^{175} I$ was counted with $>90 \%$ efficiency in a gamma-counter.

\section{Results}

\section{Enkephalin content of ganglia}

To test whether enkephalin was present in the superior cervical ganglion of the cat, ganglia were extracted in $0.1 \mathrm{M}$ acetic acid 


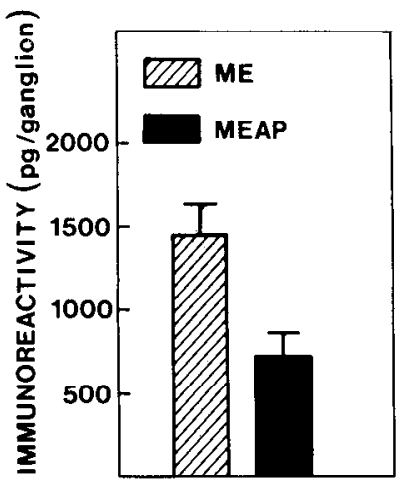

Figure 2. ME and MEAP content of the cat superior cervical ganglion. Ganglia were extracted in acid-containing PCMS $\left(10^{-4} \mathrm{M}\right)$; extracts were then subjected to reverse-phase HPLC prior to radioimmunoassay. Enkephalin-like immunoreactive material was measured in the 2 fractions shown in Figure 1, one corresponding to ME and the other to MEAP. Results represent the mean \pm SEM of 5 experiments.

and enkephalin-like immunoreactivity was determined by radioimmunoassay, using antibodies against ME. In some cases, extraction was in the presence of PCMS $\left(10^{-4} \mathrm{M}\right)$ or of bacitracin $\left(2 \times 10^{-5} \mathrm{M}\right)$. The results showed measurable enkephalin-like immunoreactivity in ganglion extracts (see Table 1); recovery of enkephalin-like immunoreactivity from extracts was enhanced when PCMS, but not bacitracin, was added to the extraction medium, indicating that the former, but not the latter, can prevent enzymatic degradation of enkephalins by this tissue in vitro.

Recovery of enkephalin-like immunoreactivity from ganglia was enhanced when acid extracts were first subjected to reversephase HPLC prior to radioimmunoassay. In these experiments, ganglia were extracted with acetic acid and PCMS. Assay of samples after HPLC yielded a value for total immunoreactive enkephalin of $2209 \pm 513 \mathrm{pg} /$ ganglion, about $75 \%$ more than was measured by radioimmunoassay alone. More importantly, this enkephalin-like immunoreactivity was recovered in 2 separate fractions from HPLC (Fig. 1A). Enkephalin-like immunoreactivity in the first fraction eluted with a retention time that corresponded to a standard of ME (Fig. 1B), and immunoreactivity in the second fraction corresponded to a standard of MEAP (Fig. 1B). The 2 "peaks" of immunoreactive material were clearly distinct (Fig. 1). Immunoreactivity in "peak 2" was recovered in 2 consecutive fractions: This might be the result of the broad resolution on HPLC of the heptapeptide (Fig. 1B), such that elution occurs over 2 fractions.

As mentioned in Materials and Methods, the antibody used in the radioimmunoassay partly cross-reacted with LE and MEAGL, and attention was given to these 2 peptides. Both LE and MEAGL would be expected to elute in the 27-28 min fraction, but there was no peak corresponding to LE or MEAGL in this fraction (Fig. 1). However, the possibility that a part of the second "peak" was MEAGL cannot be completely eliminated. If one takes into account the lag time $(0.2 \mathrm{~min})$ between the chromatogram and collection of fractions, the retention time of MEAGL, and the sharp resolution on HPLC of the octapeptide, it is likely that most of the MEAGL-like immunoreactivity elutes in the fraction between "peak 1" and "peak 2" and that only a small amount elutes in "peak 2" (Fig. 1 $A$ ).

The results of 5 experiments are summarized by Fig. 2: $66.2 \pm$ $11.6 \%$ of the enkephalin-like matcrial comigrated on HPLC with authentic ME and $33.1 \pm 13.4 \%$ with MEAP (Fig. 2).

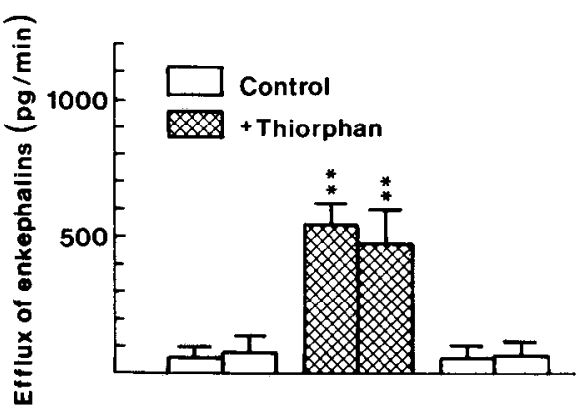

Figure 3. Efflux of enkephalins from ganglia. Effluents from ganglia perfused first in the absence (control) and then in the presence of thiorphan $\left(10^{-4} \mathrm{M}\right)$ were assayed for their enkephalin-like immunoreactivity. Efflux is expressed as picograms of enkephalin-like material effluxing per minute. Results are the mean \pm SEM of 7 experiments. ${ }^{* *}$, Significantly different from efflux in the absence of thiorphan (Student's paired $t$ test; $p<0.01$ ).

\section{Efflux of ME and MEAP from ganglia}

In 7 experiments, ganglia were perfused with Krebs medium and effluent was collected for radioimmunoassay. There was measurable immunoreactivity in perfusates, and this was increased in the presence of thiorphan (Fig. 3). By HPLC, the immunoassayable activity of ganglionic effluents was separated into 2 peaks: one co-eluted with ME and represented $84.5 \pm$ $11 \%(n=5)$ of the total immunoreactivity; the other $(15.5 \pm$ $7 \%$ ) corresponded to MEAP. A few experiments tested whether preganglionic stimulation $(20 \mathrm{~Hz})$ altered efflux of enkephalinlike immunoreactivity; the test was negative.

\section{Effects of exogenous $M E$ on $A C h$ release from ganglia}

To test whether exogenous ME affects $\mathrm{ACh}$ release, ganglia were perfused with a stable analog of methionine-enkephalin, DAEA. Ganglia were first perfused with normal Krebs medium and evoked $\mathrm{ACh}$ release during preganglionic stimulation at $20 \mathrm{~Hz}$ was measured. Then, ganglia were perfused with DAEA in a cumulative-concentration schcdulc $\left(10^{-9}-10^{-5} \mathrm{M}\right)$, and $\mathrm{ACh}$ rclease was determined for each concentration of peptide. As shown in Figure 4, DAEA had little or no effect on evoked ACh release. A higher concentration $\left(10^{-4} \mathrm{M}\right)$ of DAEA similarly did not alter evoked ACh release from ganglia: Release in the presence of DAEA was $110 \pm 19 \%$ of that in its absence.

Studies on the central effects of DAEA have shown that the analgesia produced by intracerebroventricular injection of this analog can be potentiated by inhibitors of "enkephalinase" (Algeri et al., 1981; Chipkin et al., 1982), suggesting that DAEA might be subject to "enkephalinase" degradation. Thus, in other experiments, we tested whether thiorphan, an enkephalinase inhibitor (Rogues et al., 1980; Schwartz et al., 1981; Schwartz, 1983), enhanced the effect of DAEA. The test was negative: In the presence of thiorphan $\left(10^{-4} \mathrm{M}\right)$, DAEA appeared to depress evoked ACh release modestly ( $85 \pm 15 \%)$, but this depression was not more than that seen with thiorphan $(85 \pm 9 \%)$ alone.

Spontaneous ACh release from ganglia was not significantly affected by DAEA: Release in the presence of the analog ranged from $6.3 \pm 1.2\left(10^{-9} \mathrm{M}\right)$ to $7.1 \pm 3.2 \mathrm{pmol} / \mathrm{min}\left(10^{-4} \mathrm{M}\right)$, compared to $5.0 \pm 0.9 \mathrm{pmol} / \mathrm{min}$ in its absence.

\section{Effects of exogenous MEAP on ACh release}

The purpose of these experiments was to test whether MEAP can effect ACh release. Ganglia were first perfused with normal 


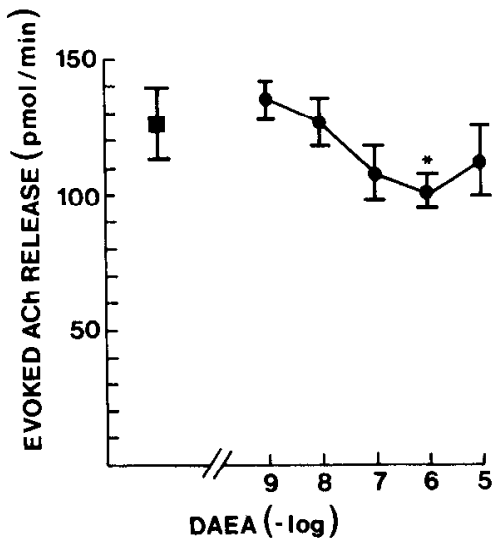

Figure 4. Effect of DAEA, $10^{-9}-10^{-5} \mathrm{M}(\bullet)$, on evoked $(20 \mathrm{~Hz}) \mathrm{ACh}$ release. Results are expressed as the mean \pm SEM of 4 experiments. *, Significantly different from control $(\square)$, release in the absence of DAEA (Student's paired $t$ test; $p<0.05$ ).

Krebs solution and $\mathrm{ACh}$ release during preganglionic stimulation $(20 \mathrm{~Hz})$ was evaluated; then, ganglia were perfused with increasing concentrations of MEAP $\left(10^{-9}-10^{-6} \mathrm{M}\right)$, and ACh release was again measured for each concentration of peptide. In contrast to the ME analog, MEAP significantly depressed evoked ACh release at all concentrations tested (Fig. 5, closed symbols).

To determine whether this depression of ACh release was due to an action on presynaptic opioid receptors, the opioid receptor antagonist naloxone was tested for its ability to antagonize the ME $\Lambda \mathrm{P}$ effect. In this experiment, ganglia were perfused with increasing concentrations of MEAP in the presence of naloxone $\left(10^{-6} \mathrm{M}\right)$ and the result compared to the above series in the absence of naloxone. MEAP appeared to be less effective in depressing evoked $\mathrm{ACh}$ release in the presence of naloxone (Fig. 5 , open symbols). Naloxone alone had no significant effect on evoked ACh release from ganglia (Fig. 5).

Other experiments confirmed that MEAP decreased ACh release and tested the reversal of this effect by naloxone at varying concentrations. For this test, each ganglion was perfused first without drug, then with MEAP $\left(10^{-7} \mathrm{M}\right)$, and then with MEAP together with naloxone (see Fig. 6). At a concentration of $10^{-6}$ $\mathrm{M}$, naloxone partially reversed the MEAP-induced inhibition of evoked ACh release (Fig. 6a); this antagonism was not significantly enhanced by increasing the concentration of naloxone to $10^{-5}$ м (Fig. $6 b$ ) or to $5 \times 10^{-5}$ м (Fig. $6 c$ ). At these higher concentrations of antagonist, naloxone itself appeared to depress evoked ACh release (Fig. 6,b,c).

Spontaneous ACh release was not significantly affected by either naloxone or MEAP or their combination (Table 2).

\section{Effect of exogenous MEAGL on ACh release}

Because HPLC of ganglion extracts did not entirely eliminate the possibility that MEAGL contributed to endogenous opioid peptides measured, we tested its effect on ACh release from the cat superior cervical ganglion. Ganglia were first perfused with normal Krebs medium, following which they were perfused with increasing concentrations $\left(10^{-9}-10^{-7} \mathrm{M}\right)$ of the octapeptide. Unlike the heptapeptide MEAP, MEAGL did not significantly affect evoked ACh release: Release in the presence of $10^{-9}, 10^{-8}$, and $10^{\circ} M$ MEAGL was $98 \pm 2,93 \pm 5$, and $90 \pm 7 \%$ of that in its absence, respectively. Thus, MEAGL is similar to ME in

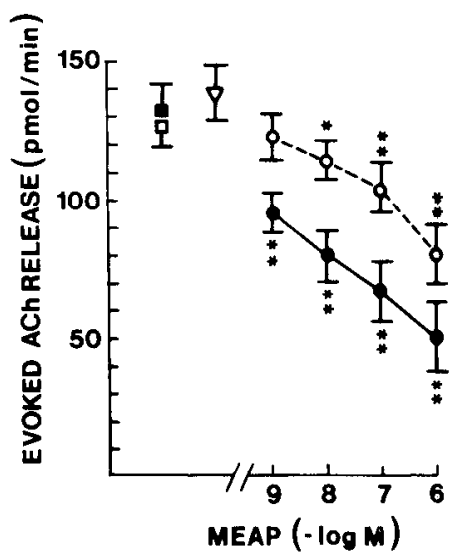

Figure 5. Effects of MEAP and naloxone on evoked $(20 \mathrm{~Hz}) \mathrm{ACh}$ release. Ganglia were perfused first with normal Krebs medium $(\square, \square)$ and then with medium containing increasing concentrations of MEAP, $10^{-9}-10^{-6} \mathrm{M}(\odot)$, or were perfused with naloxone, $10^{-6} \mathrm{M}$, first in the absence of MEAP $(\nabla)$ and then in the presence of increasing concentrations of MEAP $(O)$. Results are expressed as the mean \pm SEM of 4 experiments in each set. Release of $\mathrm{ACh}$ in the presence of MEAP is significantly different from that in its absence $\left({ }^{*} p<0.05,{ }^{* *} p<0.01\right)$. Release in the presence of naloxone, $10^{-6} \mathrm{M}$, and MEAP, $10^{-8}-10^{-6} \mathrm{M}$, is significantly different from control $\left({ }^{*} p<0.05,{ }^{* *} p<0.01\right)$.

this respect. In addition, the peptide did not alter spontaneous ACh release from the ganglion: Release in the presence of peptide ranged from $6.5 \pm 1.1\left(10^{-9} \mathrm{M}\right)$ to $8.9 \pm 2.3\left(10^{-7} \mathrm{M}\right) \mathrm{pmol} /$ min compared to $4.7 \pm 2.2 \mathrm{pmol} / \mathrm{min}$ in its absence.

\section{Discussion}

The present study was undertaken to determine if enkephalins can alter ACh release in the cat superior cervical ganglion. First, we measured the content of and efflux of endogenous enkephalins in this ganglion; second, we tested the effect of exogenous enkephalins on $\mathrm{ACh}$ release; third, we determined if this effect was the result of activation of presynaptic opioid receptors, that is, if it was naloxone-sensitive.

Endogenous opioid pentapeptides were first identified in brain extracts (Hughes et al., 1975). Since then, various peptides with opioid activity, including the heptapeptide and octapeptide enkephalins, have been found in brain and other tissues. The heptapeptide MEAP was initially purified from bovine adrenal extracts (Stern et al., 1979) and shortly thereafter from brain extracts of several species (Rossier et al., 1980). MEAP has also been detected in sympathetic ganglia, perhaps coexisting with the pentapeptide ME (Tang et al., 1982; Helen et al., 1984; Wang et al., 1984; see also Panula et al., 1984). In these ganglia, ME has been shown to be localized in preganglionic nerve fibers, in small intensely fluorescent cells, and in catecholamine-containing principal ganglion cells (DiGiulio et al., 1978; Schultzberg et al., 1979). In contrast, MEAP has been identified as yet only in preganglionic nerve fibers (see Helen et al., 1984). The present results demonstrate that both the penta- and heptapeptide enkephalins, ME and MEAP, appear to be present in the cat superior cervical ganglion, and in this respect it resembles other sympathetic ganglia (see above). Furthermore, the present experiments measured an efflux of both ME and MEAP into perfusate collected from the perfused ganglion preparation. This suggests that efflux of peptides could have functional significance, although the evidence should be considered preliminary at this stage. It is not yet clear what concentration of peptide 

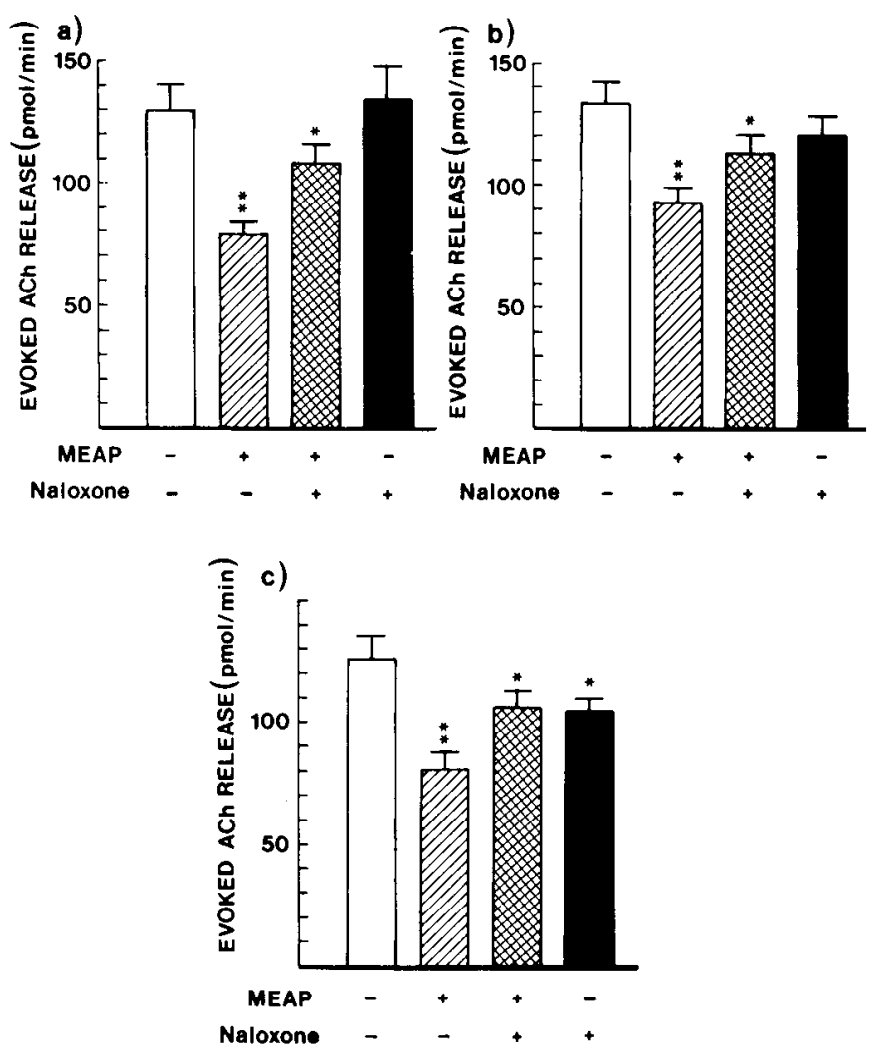

Figure 6. Effect of naloxone on the inhibition of evoked $(20 \mathrm{~Hz}) \mathrm{ACh}$ release by $10^{-7} \mathrm{M}$ MEAP (䝮). Partial reversal of the MEAP effect by $10^{-6} \mathbf{M}(a), 10^{-5} \mathrm{M}(b)$, and $5 \times 10^{-5} \mathrm{M}(c)$ naloxone. Results are expressed as the mean \pm SEM of 4 experiments. ${ }^{*}$, Significantly different from control, i.e., release in the absence of either MEAP or naloxone $(p<$ $0.01)$.

would be evident at the cholinergic synapse nor what factors might change such a concentration; in the present experiments, preganglionic stimulation at $20 \mathrm{~Hz}$ did not alter ME efflux, although it remains possible that other stimulation parameters would.

The main objective of this study was to test whether enkephalins-which, as shown by our results, are present in the cat superior cervical ganglion - have any effect on ACh release. To this end, we tested the effects of exogenous penta-, hepta-, and octapeptide on spontaneous and evoked ACh release from the cat superior cervical ganglion. The stable analog of ME, DAEA, had little or no effect on $\mathrm{ACh}$ release from the perfused superior cervical ganglion of the cat. This contrasts with the findings of Konishi and coworkers (1979), who showed that in the guinea pig, DAEA depressed EPSPs in the inferior mesenteric and celiac-superior ganglion by presynaptic inhibition of ACh release. Similar results were obtained for the superior cervical ganglion of rat and rabbit (Dun and Karczmar, 1981), where both metand leu-enkephalin depressed EPSPs by reducing ACh release from presynaptic nerve terminals. The reason for the different results obtained in the present study is not clear: It could reflect different mechanisms of regulation of ACh release between species, or between perfused and isolated preparations, or it could be the result of differences in parameters of stimulation.

Unlike ME, MEAP significantly depressed evoked ACh release. This effect of MEAP was concentration dependent and was partially reversed by naloxone. Although it is known that MEAP can be metabolized in vitro by a dipeptidyl carboxypep-
Table 2. Effects of MEAP and naloxone on spontaneous ACh release from ganglia

\begin{tabular}{lll}
$\begin{array}{l}\text { MEAP } \\
\text { (M) }\end{array}$ & $\begin{array}{l}\text { Naloxone } \\
(\mathrm{M})\end{array}$ & $\begin{array}{l}\text { Spontaneous ACh } \\
\text { release } \\
\text { (pmol/min) }\end{array}$ \\
\hline$A$ & & \\
- & - & $4.8 \pm 1.4$ \\
$10^{-9}$ & - & $5.2 \pm 1.3$ \\
$10^{-8}$ & - & $5.1 \pm 1.5$ \\
$10^{-7}$ & - & $5.6 \pm 1.1$ \\
$10^{-6}$ & - & $6.9 \pm 1.7$ \\
$B$ & & \\
- & - & $5.4 \pm 1.1$ \\
- & $10^{-6}$ & $5.6 \pm 1.7$ \\
$10^{-9}$ & $10^{-6}$ & $6.5 \pm 2.1$ \\
$10^{-8}$ & $10^{-6}$ & $5.9 \pm 1.1$ \\
$10^{-7}$ & $10^{-6}$ & $6.3 \pm 1.5$ \\
$10^{-6}$ & $10^{-6}$ & $7.2 \pm 1.9$
\end{tabular}

The results are expressed as the mean \pm SEM of 4 experiments in each set (A and B). Release in the presence of MEAP or naloxone or both is not significantly different from that in their absence $(-)(p>0.05)$.

tidase (see Yang et al., 1981; Lindberg et al., 1982a, b; Hersh, 1984), thereby releasing ME, the effects of the heptapeptide in the present experiments are unlikely to be the result of this, since DAEA was shown to have no effect on ACh release. Therefore, in the cat superior cervical ganglion, it appears that MEAP might be processed from its precursor and function as an opioid agonist in its own right.

Several findings, including the results reported here, support the hypothesis that MEAP is not only an intermediate in the synthesis of ME. First, the distribution of the 2 peptides is not always parallel (Tang et al., 1982; Williams and Dockray, 1982, 1983). Second, MEAP has been shown to be released in a calcium-dependent manner by high $\mathrm{K}^{+}$from rat and guinea pig lung slices (Tang et al., 1983) and from rat striatal slices (Patey et al., 1985). Third, the heptapeptide was shown to be more potent than the pentapeptide in the following tests: inhibition of the electrically induced twitch of the guinea pig ileum (Rossier et al., 1980), analgesia induced by intracerebroventricular administration to mice (Inturrisi et al., 1980), and inhibition of ACh-induced catecholamine secretion from chromaffin cells in culture (Saiani and Guidotti, 1982).

The results of our study show that the effect of MEAP in depressing evoked ACh release from the ganglion is only partially antagonized by naloxone. The reason for this partial reversal is not clear. It is possible that part of the effect of MEAP on ACh release is mediated by nonopiate metabolites such as Arg-Phe or Phe-Met-Arg-Phe, which are known, for example, to have cardiovascular effects (for a review, see Holaday, 1983). Alternatively, it may be that at least part of the action of the heptapeptide is mediated by a nonopioid receptor or by an opioid receptor that is relatively insensitive to naloxone, that is, not of either the mu- or delta-receptor subtype. This suggestion is supported by the insensitivity of ACh release to morphine (see MacIntosh and Collier, 1976), a mu-opiate receptor agonist, and to ME (present results), a delta-opiate receptor agonist.

Saiani and Guidotti (1982) reported that cultured chromaffin cells bind MEAP with high affinity to an opiate receptor that 
exhibited a high affinity in binding studies for etorphine and low affinity for $\mathrm{D}-\mathrm{Ala}^{2}$-D-Leu-enkephalin (a delta-opiate receptor agonist), ethylketazocine (a kappa-receptor agonist), and morphine (a mu-receptor agonist). Recently, Castanas et al. (1985) have also reported the existence in bovine adrenal medulla of an opiate receptor that binds etorphine with high affinity but not ethylketocyclazocine or dynorphin(1-13), and therefore is not of the kappa-1 subtype. Furthermore, this receptor was shown to have a high affinity for MEAP but not for ME or MEAGL (a kappa-2 agonist) and was not very sensitive to naloxone. The results of the present study on the cat superior cervical ganglion could be explained if this subtype of kappa-receptor ("new site" or kappa-3) were to exist on the preganglionic nerve terminals: First, neither ME nor MEAGL altered ACh release, but MEAP did; second, this effect of MEAP was only partially antagonized by concentrations of naloxone as high as $10^{-5}$ and $5 \times 10^{-5} \mathrm{M}$. The possible existence of this kappa-3 subtype of opioid receptor on preganglionic sympathetic nerve terminals requires testing by further experiments.

The exact mechanism by which MEAP depresses ACh release is not yet clear. It has been suggested that the binding of opiates to their receptors can reduce transmitter release by a calciumsensitive mechanism, possibly by decreasing $\mathrm{Ca}^{2+}$ influx into neural lissue (for a review, see White et al., 1985). The present results are not inconsistent with this hypothesis: Only evoked $\mathrm{ACh}$ release, which is calcium-dependent (see, for example, MacIntosh and Collier, 1976), was altered by MEAP; spontaneous $\mathrm{ACh}$ release, which is calcium-independent (see Boksa and Collier, 1980), was not affected by the peptide.

In summary, the present results provide convincing evidence that MEAP can act as an opioid agonist in the superior cervical ganglion, independent of its ability to function as a precursor for $\mathrm{ME}$. The results are consistent with the existence of a kappa-3 subtype of opioid receptor on the preganglionic nerve terminals, and in this respect, the cat superior cervical ganglion might resemble the adrenal chromaffin cell.

\section{References}

Algeri, S., M. Altstein, G. M. deSimone, and V. Guardabasso (1981) In vivo potentiation of [D-Ala $\left.{ }^{2}\right]$ Met-enkephalin amide central effects after administration of an enkephalinase inhibitor. Eur. J. Pharmacol. 74: 261-262.

Audigier, Y., H. Mazarguil, J. Rossier, and J. Cros (1980) Met-enkephalin $\left[\mathrm{Arg}^{6}, \mathrm{Phe}^{7}\right]$ interacts with the $\kappa$-receptors on guinea-pig ileum. Eur. J. Pharmacol. 68: 237-238.

Boksa, P., and B. Collier (1980) Spontaneous and evoked release of acetylcholine and a cholinergic false transmitter from brain slices: Comparison to true and false transmitter in subccllular stores. Neuroscience 5: 1517-1532.

Castanas, E., N. Bourhim, P. Giraud, F. Boudouresque, P. Cantau, and C. Oliver (1985) Interaction of opiates with opioid binding sites in the bovine adrenal medulla: II. Interaction with $\kappa$ sites. J. Neurochem. 45: 688-699.

Chipkin, R. E., M. Z. Latranyi, L. C. Iorio, and A. Barnett (1982) Potentiation of $\left[\mathrm{D}-\mathrm{Ala}^{2}\right]$ Enkephalinamide analgesia in rats by thiorphan. Eur. J. Pharmacol. 83: 283-288.

Collier, B., and Y. N. Kwok (1982) Superior cervical ganglion: Chemical considerations. In Progress in Cholinergic Biology: Model Cholinergic Synapses, I. Hanin and A. M. Goldberg, eds., pp. 169-190, Raven, New York.

Comb, M., P. H. Seeburg, J. Adelman, L. Eiden, and E. Herbert (1982) Primary structure of the human Met- and Leu-enkephalin prccursor and its mRNA. Nature 295: 663-666.

Dalsgaard, C.-J., T. Hökfelt, L.-G. Elfvin, and L. Terenius (1982) Enkephalin-containing sympathetic preganglionic neurons projecting to the inferior mesenteric ganglion: Evidence from combined retrograde tracing and immunohistochemistry. Neuroscience $7: 2039-2050$.
DiGiuliu, A. M., H.-Y. T. Yang, B. Lutold, W. Fratta, J. Hong, and E. Costa (1978) Characterization of enkephalin-like material extracted from sympathetic ganglia. Neuropharmacology 17: 989-992.

DiGiulio, A. M., H.-Y. T. Yang, W. Fratta, and E. Costa (1979) Decreased content of immunoreactive enkephalin-like peptide in peripheral tissues of spontaneously hypertensive rats. Nature 278: 646647.

Dun, N. J. (1983) Peptide hormones and transmission in sympathetic ganglia. In Autonomic Ganglia, L.-G. Elfvin, ed., pp. 345-366, Wiley, London.

Dun, N. J., and A. G. Karczmar (1981) Multiple mechanisms in ganglionic transmission. In Cholinergic Mechanisms: Phylogenetic Aspects, Central and Peripheral Synapses, and Clinical Significance, G. Pepeu and H. Ladinsky, eds., pp. 109-118, Plenum, New York.

Fonnum, F. (1969) Radiochemical microassays for the determination of choline acetyltransferase and acetylcholinesterase activities. Biochem. J. 115: 465-472.

Goldberg, A. M., and R. E. McCaman (1973) The determination of picomole amounts of acetylcholine in mammalian brain. J. Neurochem. 20: 1-8.

Gubler, U., P. Seeburg, B. J. Hoffman, L. P. Gage, and S. Udenfriend (1982) Molecular cloning establishes proenkephalin as precursor of enkephalin-containing pepiides. Nature 29:5: 206-208.

Hársing, L. G., Jr., A. Z. Rónai, G. T. Somogyi, H. Umezawa, S. Bájusz, and E. S. Vizi (1984) Met $^{5}$-enkephalin-Arg ${ }^{6}-\mathrm{Phe}^{7}$ inhibition of noradrenaline and acetylcholine release from peripheral organs. J. $\mathrm{Au}$ tonom. Pharmacol. 4: 33-43.

Helen, P., P. Panula, H.-Y. T. Yang, A. Hervönen, and S. I. Rapoport (1984) Location of Substance P-, bombesin-gastrin-releasing peptide, $\left[\mathrm{Met}^{5}\right]$ Enkephalin- and [Met $\left.{ }^{5}\right]$ Enkephalin-Arg ${ }^{6}-\mathrm{Phe}^{7}$-like immunoreactivities in adult human sympathetic ganglia. Neuroscience 12: 907-916.

Hersh, L. B. (1984) Reaction of opioid peptides with neutral endopeptidase ("enkephalinase"). J. Neurochem. 43: 487-493.

Holaday, J. W. (1983) Cardiovascular effects of endogenous opiate systems. Annu. Rev. Pharmacol. Toxicol. 23: 541-594.

Hughes, J., T. W. Smith, H. W. Kosterlit7, I. H. Fothergill, B. A. Morgan, and H. R. Morris (1975) Identification of two related pentapeptides from the brain with potent opiate agonist activity. Nature 258: 577-579.

Inturrisi, C. E., J. G. Umans, D. Wolff, A. S. Stern, R. V. Lewis, S. Stein, and S. Udenfriend (1980) Analgesic activity of the naturally occurring heptapeptide [Met]enkephalin-Arg ${ }^{6}-$ Phe$^{7}$. Proc. Natl. Acad. Sci. USA 77: 5512-5514.

Kibjakow, A. W. (1933) Über humorale Übertragung der Erregung von einem Neuron auf das Andere. Pfluegers Arch. Physiol. 232:432443.

Konishi, S., A. Tsunoo, and M. Otsuka (1979) Enkephalins presynaptically inhibit cholinergic transmission in sympatetic ganglia. Nature 282: 515-516.

Konishi, S., A. Tsunoo, and M. Otsuka (1981) Enkephalin as a transmitter for presynaptic inhibition in sympathetic ganglia. Nature 294 : $80-82$.

Kwok, Y. N., and B. Collier (1982) Synthesis of acetylcholine from acetate in a sympathetic ganglion. J. Neurochem. 39: 16-26.

Lindberg, I., H.-Y. T. Yang, and E. Costa (1982a) An enkephalingenerating enzyme in bovine adrenal medulla. Biocherr. Res. Commun. 106: 186-193.

Lindberg, I., H.-Y. T. Yang, and E. Costa (1982b) Characterization of a partially purified trypsin-like enkephalin-generating enzyme in bovine adrenal medulla. Life Sci. 31: 1713-1716.

MacIntosh, F. C., and B. Collier (1976) Neurochemistry of cholinergic terminals. In Neuromuscular Junction, E. Zaimis, ed., pp. 99-228, Springer-Verlag, Berlin.

Noda, M., Y. Furutani, H. Takahashi, M. Toyosato, T. Hirosa, S. Inayama, S. Nakanishi, and S. Numa (1982) Cloning and sequence analysis of cDNA for bovine adrenal preproenkephalin. Nature 295 : 202-206.

Panula, P., H.-Y. T. Yang, and E. Costa (1984) Coexistence of met ${ }^{5}$ enkephalin-Arg ${ }^{6}-\mathrm{Phe}^{7}$ with $\mathrm{met}^{5}$-enkephalin and the possible role of met ${ }^{5}$-enkephalin- $\mathrm{Arg}^{6}-\mathrm{Phe}^{7}$ in neuronal function. In Coexistence of Neuroactive Substances in Neurons, V. Chan-Palay and S. L. Palay, eds., pp. 113-126, Wiley, New York.

Patey, G., A. Cupo, H. Mazarguil, J.-L. Morgat, and J. Rossier (1985) Release of proenkephalin-derived opioid peptides from rat striatum in vitro and their rapid degradation. Neuroscience 15: 1035-1044. 
Roques, B. P., M. C. Fournié-Zaluski, E. Soroca, J. M. Lecomte, B. Malfroy, C. Llorens, and J.-C. Schwartz (1980) The enkephalinase inhibitor thiorphan shows antinociceptive activity in mice. Nature 288: 286-288.

Rossier, J., Y. Audigier, N. Ling, J. Cros, and S. Udenfriend (1980) Met-enkephalin-Arg ${ }^{6}-\mathrm{Phe}^{7}$, present in high amounts in brain of rat, cattle and man, is an opioid agonist. Nature 288: 88-90.

Saiani, L., and A. Guidotti (1982) Opiate receptor-mediated inhibition of catecholamine release in primary cultures of bovine adrenal chromaffin cells. J. Neurochem. 39: 1669-1676.

Schultzberg, M. (1984) Overviews of colocalization of peptides in the peripheral nervous system. In Coexistence of Neuroactive Substances in Neurons, V. Chan-Palay and S. L. Palay, eds., pp. 225-244, Wiley, New York.

Schultzberg, M., T. Hökfelt, J. M. Lundberg, L. Terenius, L.-G. Elfvin, and R. P. Elde (1978a) Enkephalin-like immunoreactivity in nerve terminals in sympathetic ganglia and adrenal medulla and in adrenal medullary gland cells. Acta Physiol. Scand. 103: 475-477.

Schultzberg, M., J. M. Lundberg, T. Hökfelt, L. Terenius, J. Brandt, R. P. Elde, and M. Goldstein (1978b) Enkephalin-like immunoreactivity in gland cells and nerve terminals of the adrenal medulla. Neuroscience 3: 1169-1186.

Schultzberg, M., T. Hökfelt, L. Terenius, L.-G. Elfvin, J. M. I undberg, J. Brandt, R. P. Elde, and M. Goldstein (1979) Enkephalin immunoreactive nerve fibers and cell bodies in sympathetic ganglia of the guinea-pig and rat. Neuroscience 4: 249-270.

Schwartz, J.-C. (1983) Metabolism of enkephalins and the inactivating neuropeptidase concept. Trends Neurosci. 6: 45-48.

Schwartz, J.-C., B. Malfroy, and S. de la Baume (1981) Biological inactivation of enkephalins and the role of enkephalin-dipeptidyl- carboxypeptidase ("enkephalinase") as neuropeptidase. Life Sci. 29. $1715-1740$.

Stern, A. S., R. V. Lewis, S. Kimura, J. Rossier, L. D. Gerber, L. Brink, S. Stein, and S. Udentriend (1979) Isolation of the opioid heptapeptide Met-enkephalin [ $\left.\mathrm{Arg}^{6}, \mathrm{Phe}^{7}\right]$ from bovine adrenal medullary granules and striatum. Proc. Natl. Acad. Sci. USA 76: 6680-6683.

Tang, J., H.-Y. T. Yang, and E. Costa (1982) Distribution of Metenkephalin-Arg ${ }^{6}-\mathrm{Phe}^{7}$ in various tissues of rats and guinea pigs. Neuropharmacology 21: 595-600.

Tang, J., J. Chou, A. Z. Zhang, H.-Y. T. Yang, and E. Costa (1983) Met $^{5}$-enkephalin-Arg ${ }^{6}-\mathrm{Phe}^{7}$ and its receptor in lung. Life Sci. 32: 23712377.

Wang, Y.-N., A. C. Church, and R. J. Wyatt (1984) Localization of $\mathrm{Met}^{5}$-enkephalin-Arg ${ }^{6}-\mathrm{Phe}^{7}$-like immunoreactivity in the rat gastrointestinal tract. Neurosci. Lett. 51:319-324.

White, J. D., K. D. Stewart, J. E. Krause, and J. F. McKelvy (1985) Biochemistry of peptide-secreting neurons. Physiol. Rev. 65: 553606.

Williams, R. G., and G. J. Dockray (1982) Differential distribution in rat basal ganglia of Met-enkephalin and Met-enkephalin $\mathrm{Arg}^{6} \mathrm{Phe}^{7}$ like peptides revealed by immunohistochemistry. Brain Res. 240: 167-170.

Williams, R. G., and G. J. Dockray (1983) Distribution of enkephalinrelated peptides in rat brain: Immunohistochemical studies using antisera to met-enkephalin and met-enkephalin $\mathrm{Arg}^{6} \mathrm{Phe}^{7}$. Neuroscience 9: $563-586$.

Yang, H.-Y. T., E. Majane, and E. Costa (1981) Conversion of [Met ${ }^{5}$ ]enkephalin-Arg ${ }^{6}-\mathrm{Phe}^{7}$ to $\left[\mathrm{Met}^{5}\right]$-enkephalin by dipeptidyl carboxypeptidase. Neuropharmacology 20: 891-894. 